\title{
The World Bank's Discourse on Social Inequality: A Policy of Appeasement?
}

\author{
Olivia G. Merritt ${ }^{1} \&$ Neena L. Chappel1 ${ }^{1,2}$ \\ ${ }^{1}$ Department of Sociology, University of Victoria, Canada \\ ${ }^{2}$ Centre on Aging, University of Victoria, Canada \\ Correspondence: Olivia G. Merritt, Department of Sociology, University of Victoria, Canada. E-mail: om@meritus.ca
}

Received: June 19, 2014

Accepted: July 1, $2014 \quad$ Available online: August 8, 2014

doi:10.11114/ijsss.v2i4.446

URL: http://dx.doi.org/10.11114/ijsss.v2i4.446

\begin{abstract}
Locating 'social justice' and 'social consciousness' as new buzzwords in dominant economic development paradigms, this paper explores the contradictions between discourse and economic structure in recent social policy programs implemented through World Bank involvement in Latin America (2000-2012). The authors use a critical discourse analysis technique to analyze official World Bank documents pertaining to two projects, the Jefes de Hogar (Argentina) and the Bolsa Familia (Brazil). The study concluded that social justice/quality of life discourse was used in a superficial manner, with the overarching goals of World Bank social policy remaining to be the hegemonic safeguarding of global neoliberal economic-political structures.
\end{abstract}

Keywords: Social inequality, Latin America, human capital, development discourses, World Bank, neoliberalism.

\section{Introduction}

From historically having among the worst social inequality in the world, several Latin American nations, including Argentina and Brazil, have seen drastic decreases in social inequality during the past 10 years (Gottschalk \& Justino, 2005; Lustig, Lopez-Calva, \& Ortiz-Juarez, 2012)). The implementation of national social policies supported by the World Bank (WB), along with a strong political shift towards left-of-centre (LOC) positions since the early $21^{\text {st }}$ century, have been suggested as causes for the significant drop in social inequality. On the one hand, from the 1980s to the present, many researchers have argued that the WB's involvement in Latin American economies has spawned significant increases in social inequality and poverty due to the implementation of WB neoliberal policies (Abouharb \& Cingranelli, 2007; McNally, 2006; Wall, 2005). Alternatively, others have argued that a recent shift in WB policy, characterized by a substantive concern for fostering human rights and freedoms, a form of development which adheres to a social and environmental consciousness (Ruger, 2005; Goldman, 2007), has contributed to the decrease. This paper assesses the validity of such sweeping claims of an evolving WB social conscience, examining the current rationale underpinning the WB agenda on social inequality as presented in the discourse of WB policy documents from Argentina and Brazil.

\subsection{The World Bank and its Policy Rhetoric}

From the 1980s to the present, the WB, in corroboration with the International Monetary Fund (IMF) and the World Trade Organization (WTO), has "advocated the so-called Washington Consensus of fiscal austerity (government spending cuts), privatization and market liberalization" (Wall, 2005, p. 28). The focus of the WB and IMF is to promote growth through neoliberal economic reforms supporting private property rights and an unregulated free market while also promoting better governance including weeding out corruption (Abouharb \& Cingranelli, 2007). However, McNally (2006) argues that globalizing organizations, such as the WB, IMF, and WTO, have historically precipitated increases in social inequalities through bargaining for neoliberal/free-market-style economic restructuring. From this perspective, the globalizing strategies promoted by the WB have increased the wealth of developed nations' multinational corporations while simultaneously increasing the economic and political marginality of South America's poorest poor, flagrantly dispossessing these nation-states of their national wealth (McNally, 2006; Wall, 2005). Alternatively, neoliberal proponents remain fixed, proselytizing that the trickle-down effects of free-market expansion benefit developing nations. 
A significant change in WB policy occurred at the end of the 20th century. Its purview shifted, with global health issues and the social welfare of loaning states' populations garnering a larger focus ... at least discursively (Ruger, 2005; Goldman, 2007). Especially since 2002, the WB has focused its discourse on pro-poor rhetoric and the achievement of health and social goals; for example, "Today's Bank ... has sharpened its focus on poverty reduction as the overarching goal of all its work" (World Bank, 2013b). This trend of increased concern for public issues beyond the economic is seen in the WB's shift in personnel: "It [WB] once had a homogeneous staff of engineers and financial analysts, based solely in Washington, D.C. Today, it has a multidisciplinary and diverse staff including economists, public policy experts, sectoral experts, and social scientists. 40 percent of staff are now based in country offices" (WB, 2013b).

Indeed, the WB Annual Report 2002 catalogued a 'revolutionary' shift in its positioning on the issue of poverty and quality of life for all. In this report, the WB asserts its commitment to attain the United Nations' Millennium Development Goals (MDGs) through its policies, administration, and funding-grants. The renewed vision is said to represent an expanded vision with the "objective of halving world poverty by 2015" (WB, 2002b). The WB's re-envisioned goals include the MDGs: eradicating extreme poverty and hunger; achieving universal primary education; promoting gender equality and empowering women; reducing child mortality; improving maternal health; combating HIV/AIDS, malaria, and other diseases; ensuring environmental sustainability; and developing a global partnership for development (WB, 2002b).

Academic researchers such as Ruger (2005) attest that the WB is both deepening its commitment to global social and health issues and understanding better that development is a holistic, integrated, and multidimensional task involving balancing the strengths of the market with other institutions. For Ruger (2005), the recent and evolving WB paradigm shift is increasingly people-centered as opposed to market-centered, evidenced by the fact that the WB is now the world's largest external funder of health, committing $>\$ 1$ billion annually to improve health and nutrition in developing countries. Indeed, the WB is now the most significant financier of health programs globally, surpassing the World Health Organization (WHO), and the United Nations (UN). Interestingly though, 93\% of its advisors represent commercial interests (Lee, Sridhar, \& Patel, 2009).

Goldman (2007) refers to the WB's discursive paradigm-shift as Green Neoliberalism. Using the example of WB water infrastructure projects, he illustrates a discursive attempt to soften the WB's image by heavily promoting the apparent socio-environmental benefits of privatization policies and WB investing. Goldman (2007) cites the MDGs and International Conferences on Water at Dublin and Rio de Janerio of 1992 as pivotal sources of discourse which roused the world's moral vigor to provide clean water for all people, explaining how the WB has, and is, using humanitarian discourses such as the UN's MDGs to further propagate its neoliberal policy prescriptions as a means to actuate humanitarian goals for developing nations.

Researchers such as Goldman (2007) and Munarriz (2008) highlight the apparent conundrum of an organization which fosters expansive private enterprise/imperialism, now articulating its development goals based on human rights and a concern for the social good. For example, Ruger (2005) notes that while UNICEF estimates associate as many as 500,000 deaths of young children in a 12-month period as a result of structural adjustment programs, the WB's research found no negative impact of structural adjustment operations on health expenditures and outcomes. Castro (2007) is one of many arguing that WB policies have in practice contributed to deepening existing inequalities of power rather than extending essential services to the poor, thereby eroding citizen rights and national sovereignty while making large multinational corporations rich.

Several studies examine WB discourse regarding water infrastructure development, noting that a global hegemony of how water development should proceed has been constructed. The WB establishes that only private systems of water provision are successful for the development of water infrastructure. It articulates the view that only private water system development can bring quality water to the world's poorest and most marginalized. (Notwithstanding the recent case of Uruguay's anti-privatization constitutional amendment on water that forced the world's largest water firms to pull out of its lucrative Southern markets.) Yet both private and public methods of water provision have shown strengths and weaknesses (Goldman, 2007). The WB policy shift towards a pro-poor rhetoric in the late 1990s occurred in light of increasing civil unrest in response to its neoliberal development measures. The recent discourse of public-private partnerships by the WB incorporates its concern for the poor's access to water with a concern for "broadening the market scope" (Munarriz, 2008).

The discourse in the WB's social inequality programs has received less attention than the WB's water privatization discourse and is the topic of this paper, potentially shedding light on whether WB projects promote social inequality.

\subsection{Social Inequality in Argentina and Brazil}

Historically, Latin American countries have shown the highest measures of income social inequality in the world, increasing from the 1980s until the beginning of the $21^{\text {st }}$ century. For example, in 1995 the Gini coefficient for income 
inequality was 0.56 ; during the same year in OECD countries, it was 0.37 (Gottschalk \& Justino, 2005). Importantly, high levels of inequality are a serious threat to development undertakings because social inequality negatively affects social and economic development, erodes social cohesion, and is linked to declines in population health due to social exclusion and difficulties in accessing social services and socio-political institutions (Gottschalk \& Justino, 2005). Health inequalities remain a stark example of social inequality in Latin America, including Argentina and Brazil. According to Belizán, Cafferata, Belizán, and Althabe (2007), maternal and child health indicators for those in the poorest quintile compared to the wealthiest illustrate deep disparities in health outcomes, showcasing the fundamental connection between economic inequalities and health inequalities.

The WB's role in the decrease in social inequality between 2000 and 2010 throughout 13 of 17 Latin American nations, including Argentina and Brazil, is controversial. Lustig et al. (2012) credit two underlying phenomena: a fall in premiums to skilled labour, and higher and more progressive government transfers. The fall in skilled labour premiums includes social changes such as increasing unionization, minimum wages, and market demand for skilled labour. They also point to the WB-funded programs of Jefes y Jefas de Hogar Descupados (JDH) in Argentina and Bolsa Familia Program (BFP) in Brazil as playing equalizing roles in non-labour income transfers. Additionally, changes in social security transfers include broadening pension coverage to the elderly in Argentina and increasing Beneficio de Prestacao Continuada (a payment for disabled and elderly persons) coverage in Brazil.

Cornia (2010) concurs with Lustig et al. (2012) that these social programs changed the macro-landscape of social inequality in both countries. But notably, both authors point to a decreasing shift in inequality measures throughout Latin America. Cornia (2010) credits this shift to changes in political orientation of governments across Latin America within favourable economic circumstances, which facilitated the mounting of successful social initiatives. The burgeoning disappointment of Latin American populations with the Washington Consensus policies of the 2000s also facilitated a LOC political base and the introduction of a new paradigm of economic reforms of prudent redistribution with growth. The new model relies on "managed exchange rates, a neutral or counter-cyclical fiscal policy, reduced dependence on foreign capital, rapid accumulation of reserves, and an active role of the state in the field of labour and social policies" (p. 109). Cornia (2010) notes the political shift helped increase labour participation, the share of workers covered by formal contracts, and the reduction of unemployment. This moderate LOC political movement is typified by policies that increase the tax/GDP ratio as well as raise public spending on education and social assistance. Dello Buono (2011) argues that the ideological supports which bolstered neoliberalism and social inequality in Latin America throughout the 1980s and 1990s have lost persuasive power due to changing levels of inequality and the emergence of left-leaning governments with popular support. De la Barra (2010) announces that trust in the free market system has collapsed.

On the other hand, according to several studies, the WB influence on social policy in Argentina and Brazil, and indeed within Latin America in recent history, has benefitted poor populations on a number of indicators. For example, income inequality has lessened substantially on national per capita measurements in both countries (Lustig et al., 2012; Cramer \& Kaufman, 2010). According to Santos (2010), in Brazil the BFP has been a success as poverty has significantly decreased and "more than four million people have left the indigence and another three million are no longer poor ... income distribution has improved, the Gini2 and HDI3 indexes have ameliorated and consumption, mainly in the retail sector, has increased" (p. 4). A number of health indicators have also shown improvement throughout Latin America; in a particular example, maternal health indicators have improved significantly in Brazil, presumably due in part to the maternal health conditionalities in the BFP (Hall, 2008; Etienne, 2013; Biggs, King, Basu, \& Stuckler, 2010).

The WB contends that the BFP "has shown that in a short period of time, with strong political support, good targeting, strong financial management and monitoring, especially of conditionalities, conditional cash transfers (CCTs) represent an important component of overall social policy, and can contribute to improved incomes" (WB, 2010b, p. 69). CCTs are welfare payments given to persons with limited or negligible income on the basis of their compliance with certain demands (i.e., receiving vaccinations or caring for a disabled dependent). Moreover, during the 2001-2002 Argentine economic crisis, the JDH was found to be largely successful in protecting poor persons and the unemployed from dire poverty; however, the lasting human capital impacts were less evident in comparison to the BFP results (Bourguignon \& Pereira da Silva, 2003). There are also arguments that such WB social policies have improved economic and social stability.

Nevertheless, critics point to ever-severe social inequalities within municipalities, and within regions, in Argentina and Brazil; such inequalities are both income- and health-related (Etienne, 2013; Biggs et al., 2010). In order to better understand the effects of WB social inequality projects, this study asks: What kind of rationality does the WB use to justify its social inequality projects? Does this rationality depart from the WB's free-market idealism of the 1980s and 1990s? What kind of power dynamics are manifested in the discourse of WB literature? 


\section{Methods}

\subsection{Categorizing Concepts and Variables}

Social inequality is a complex marker that can be measured by relative per-capita income, i.e., the Gini coefficient (Huber, 2009), inequalities in prestige, household living standards, political influence, social inclusion, and health (Nuruzzaman, 2007). The WB database was scoured for project articles related to social policy administration and loan funding from 2000 to 2012. The highest concentration of programs on social-spending was found in Latin America, especially Argentina and Brazil. Thus, Latin America became the focal region for this study, a region that also appears to be the focus of the WB's recent foray into social policy as related to its new MDGs vision.

Argentina and Brazil are at a similar level of development, both progressive middle-income nations in South America. Both countries' populations show comparable, high levels of social and income inequality; the WB has invested heavily in both nations' developments historically, as well as currently. Moreover, both countries have had similar trends in social inequality throughout the 1980s, 1990s, and 2000s: increasing, increasing, and then decreasing (Lustig et al., 2012). From 2000 to 2012, both were active in many WB-supported social inequality amelioration-themed projects; 17 in Argentina, 37 in Brazil. A social inequality project is defined as: that which aims through policy to attenuate disparities between groups in terms of income, resources, access to opportunity, and health and well-being (Gottschalk $\&$ Justino, 2005).

For each country, the totality of projects was categorized according to three common themes that surfaced within the analyses: a project with broad-based social-welfare goals (in close consideration with national government efforts), a rural development project (targeting the most flagrant examples of rural social inequality), and health and health-care inequality. Two broad-based WB social projects were chosen to analyze in detail using critical discourse analysis (CDA): the Jefes de Hogar (JDH) project of Argentina and the Bolsa Familia Program (BFP) of Brazil, chosen because of the substantial amount of WB literature, as well as third-party literature, concerning the projects. The data from these projects were handed-coded to search for themes and key-terms relevant to the discourse on social inequality. The search themes were standardized across the CDA for all JDH and BFP project documents.

\subsection{Selection of Sample Projects}

The Jefes de Hogar (Heads of Household) project in Argentina aimed to mitigate rapidly-rising social inequality due to the economic crisis of 2001-2002 by targeting the social determinant of unemployment. Running between 2003 and 2006, the project cost US $\$ 1,987,000,000$ in total, US $\$ 600,000,000$ of which was provided through a WB loan commitment. For this project, six WB documents are publically-available, with document lengths ranging from 11 to 154 pages. CDA was performed on the public documents, examining how the WB addressed social inequalities evident in unemployment. The WB portion of funding focused on providing workfare projects for the unemployed and impoverished from which these people could obtain monthly conditional cash transfers through the national government. Thus the JDH was promoted as an investment in community-building, a social protection measure, and a general investment in human capital (i.e., the social, educational, and health aspects of human capital). The project can be found online via the following link: http://www.worldbank.org/projects/P073578/social-protection-vi-project-jefes-de-hogar-heads-household?lang=en

The Bolsa Familia Program in Brazil articulates goals for lifting poor Brazilians from hunger and poverty and reducing income inequality; it was active between 2003 and 2009. The project focused on themes of social safety nets, vulnerability assessment and monitoring, poverty strategy assessment and monitoring, and administrative and civil service reform. National funding consisted of an initial commitment of US\$5,622,700,000, with the WB contributing an additional US $\$ 572,200,000$ while providing the bulk of the strategic planning for program implementation. The project was praised and subsequently renewed in 2010 with an additional US\$200 million grant. For the Bolsa Familia, there are 10 publically-available WB documents, which include project status briefs, strategic policy plans, and results reports. The documents range in size from two to 114 pages. The Bolsa Familia included a small focus on health, with $20 \%$ of US $\$ 4.6$ million going towards a "results-based financing for health program." The project can be found online via the following link: http://web.worldbank.org/WBSITE/EXTERNAL/NEWS/0,,contentMDK:20754490 menuPK:141310 pagePK: 34370 piPK:34424 theSitePK:4607,00.html

\subsection{Theoretical Framework}

The analysis uses a theoretical model of social constructionism, as established by Berger and Luckmann (1966), along with the Foucauldian concept of power (discursive dominance), to illustrate the key elements of how the BFP and JDH documents frame the issue of social inequality within the broader structures of society. Social constructionism assumes that society is a human product and its institutions are social-constructs, produced through common human action. Foucauldian discourse analysis is based on three premises: historical contextualization of the text; analyses of the text as a document of social, political, and historical conditions which shape and support the truth claims of the text; and the 
materiality of the text, i.e., that the discourse is not simply inconsequential, but that through this text, power is articulated and distributed with real, material effect (Hook, 2001). In the analyses presented here, the political, social, and economic conditions of the discourse production are connected to the truth content of the text; i.e., the political, social, and economic motivations of the WB in funding a specific social inequality project can be ascertained through a critical analysis of the texts' truth claims and the types of evidence used to claim validity.

\subsubsection{Critical Discourse Analysis}

CDA is appropriate in "de-mystifying ideologies and power through the systematic and retroductable investigation of semiotic data" (Wodak \& Meyer, 2009, p. 3). The ideologies within which the WB embeds its discourse on inequality are examined; the aim of this study is to grapple with the discourse of social inequality so as to comprehend the ideology the WB currently holds regarding social inequality policy.

\section{Results}

The CDA produced two central themes within the WB literature. The first is one of key contradictions between the WB's discursive framing of the projects as MDGs-motivated and its implementation methods within these projects. The second, but perhaps most prominent, theme is the WB's use of a human capital development agenda for social inequality.

\subsection{Contradictions in World Bank Discourse and in Project Implementation}

\subsubsection{Social Justice Rhetoric Obfuscates Economic Considerations}

The WB's discursive promotion of its MDGs-implementation role and its organizational goal of "freeing the world from poverty" is at odds with policy implementation and discursive framing of social inequality within the JDH and BFP project-specific documents. For example, the WB constructs itself as an organization in the full pursuit of ending poverty worldwide; indeed, the main quote on its "About Us" webpage states: "Our work is challenging, but our mission is simple: Help reduce poverty" (WB, 2013a). Furthermore, the current slogan of the World Bank Group is "working for a world free of poverty," and each of the summary project documents state that the overarching goal is "the ending of poverty worldwide" (WB, 2010b; WB, 2010a). In this way, the WB can be understood as an organization that actively socially-constructs itself as an institution motivated by a concern for social justice.

In the project-specific documents, social inequality is constructed with the idea that the JDH and BFP were instituted in order to help Argentina and Brazil achieve the MDGs - of which the amelioration of poverty and the improvement of health and education indicators are key tenets. For example, according to the WB, the BFP is successful in "Achieving a More Equitable Brazil" (WB, 2010b, p. 7). Indeed, the WB claims the BFP is "closely aligned with the Millennium Development Goals, contributing directly to the reduction of poverty and inequality, and the demand-side incentives it provided contributed to reducing malnutrition, achieving universal education, reducing child mortality and improving maternal health" (WB, 2010b, p. 7). Thus, the WB positions the BFP, and its involvement in the BFP, as efforts of social justice: achieving greater living standards and health outcomes for Brazil's populace.

Furthermore, the WB uses its discourse to position its projects as social justice; for example, in the JDH documents: "The program also succeeded in its role of social contention and helped create spaces of initial dialogue through the consultative councils in a climate where government was highly discredited" (WB, 2007, p. 17). The term "social contention" means the gaining of momentum by particular social movements - usually it is used to denote grassroots movements. By using the term, the WB positions the JDH as a social protection project that produced grassroots social movements.

Yet, the documents are written in a highly-exclusive, technocratic, and bureaucratic manner. The exclusivity of the language shows the relational-power of the WB. McCormick (2012) explains: "The linguistic and textual mechanics of development processes perpetuate exclusion. Development-speak is accessible only to those most embedded in its rapidly evolving discourse and paper trails" (p. 26). The specific rhetoric of the WB could not, presumably, be understood by poor Argentineans and Brazilians who are affected by the policies. The WB is not a grassroots organization; rather, it holds an administrative hegemony of influence over those nations and their citizens who are involved with it. The language is indicative of, and written for, a transnational educated capitalist elite. McCormick (2012) describes WB rhetoric as a kind of "acronymania," a development dialect disseminated through powerful actors in a way that obfuscates what is happening.

\subsubsection{Economic Considerations Come First}

In addition, the WB discourse of the BFP socially-constructed the dismantling of an extensive, but "regressive" (WB, 2004a, p. 8), national pension plan in order to reallocate the plan's pension funds to the BFP CCTs' budget. This change is framed as a "progressive" and "efficient" use of resources to reduce social inequality throughout Brazil, claiming that 
pension reforms would release up to $0.4 \%$ of GDP/year for other more efficient social policies (WB, 2004a, p. 8). In constructing the Brazilian national pension plan as regressive policy action on social inequality, but framing the BFP as progressive, the MDGs and "freedom from poverty" motivations are compromised. In promoting the neoliberal policy-reform of the Brazilian pension program (Brooks, 2007), WB policy implementation steers away from the MDGs by encouraging the reduction of the public pension system and instead ensuring principles of economic efficiency to "stream-line" and "consolidate" welfare payments programs into a "progressive," "unified" cash transfer system. This consolidation is a contradiction within WB economic and social goals, as cutting funds to the pension system will likely have negative impacts on the quality of life of many of the aging population (especially those without dependents or those in ill-health).

Similarly with the JDH, consolidation of social welfare programs is mandated through WB involvement: "The expected spending for the JDH, the government's main response to the economic crisis, is projected to represent about $1 \%$ of GDP in 2003" (WB, 2002a, p. 17). The consolidation of social programs to formulate one, unified, targeted program maximizes a human capital investment in the poor populations without substantially-increasing overall budget allocations to the poor people of the nation. Such re-alignment and consolidation of social programs can be seen in the JDH document discourse: "Given the context of the social crisis, the JDH Program is considered to be affordable even under a scenario of fiscal discipline, in part because the Government has eliminated other programs of social assistance and diverted funding from them to this Program" (WB, 2002a, p. 17). Thus, the JDH did not raise social spending overall, but rather diverted social spending resources to particular areas - notably to address the pressing problem of unemployment.

The UN's MDGs assert goals for quality of life for all people of a population, based on the idea of persons' inherent human rights. But the WB's JDH program in Argentina provided social protection only for certain groups of the population - notably, older adults were largely ignored: "The World Bank has identified the key vulnerable groups in Argentina as: poor children, the elderly without pension coverage, and the poor unemployed. The JDH targets the first and third key vulnerable groups - the poor unemployed with dependents under the age of 18" (WB, 2002a, p. 5). That is, the WB project was exclusionary, which runs in direct contrast to the inclusive spirit of the MDGs.

With the BFP, the WB makes particular efforts to acknowledge the special cultural and social circumstances of the indigenous and Quilombola people in Brazil. The WB recognizes that racial inequality is a part of social inequality: "As ethnic minorities, indigenous and Quilombola peoples find themselves at a disadvantaged position in terms of opportunities and quality of life prospects" (Brazil, 2004, p. 9). In response, it recommends the promotion of "citizen oversight by aboriginal or cultural group stakeholders to help propagate BFP in culturally-sensitive ways" (Brazil, 2004, p. 9). That is, there are instances where social inequity ideology/rhetoric is employed; but these instances are distinct and generally removed from the overall principles of the social policy program. Nevertheless, the use of the term "citizen oversight" strategically constructs the WB as a facilitator of social justice and citizen emancipation from dogmatic power. However, this is an ironic use of words as essentially "citizen oversight" explains a phenomenon whereby aboriginal or Quilombola individuals are co-opted by the WB and Government of Brazil to enact and disseminate BFP policies that neither originated, nor were conceived, in the cultural community in question. (See Murphy (2008) for similar descriptions of such WB programs in other developing countries.)

The WB social inequality agenda appropriates a discourse of social justice and UN MDGs to serve neoliberal development goals, confirming McCormick's (2012) claim that the WB has the power to influence the harmonization of domestic policy with overarching global neoliberal hegemonies on social inequality. For example, for the JDH program, the WB finances a portion of the CCTs and work-fare project resources, but its primary role is "to monitor implementation of the overall program and any other employment program of the government" (WB, 2002a, p. 2). The WB also plays a significant monitoring role in the creation and implementation of the BFP in Brazil (WB, 2010b). The WB's role as social program monitor is very significant; it implies the coalescence of domestic and global social policy goals, signifying the WB's power (and thus global hegemony) over domestic governments on the issue of social policy implementation.

Overall, WB social inequality projects reveal a number of fundamental contradictions in the WB development agenda. Specifically, cases of rhetoric and policy implementation illustrate a key contradiction between the goal of social justice and the goal of globalized economic growth. Murphy (2008) examines the often paradoxical mandates of the WB: to promote economic and social objectives simultaneously with developmental ends, noting that while WB social goals become increasingly aligned with the MDGs, larger macroeconomic goals maintain a philosophy of structural adjustment: export-oriented growth, reductions in the size of the public sector, and growth in privatization. Our analyses of social inequality confirm that, in policy strategies specifically propagandized to ameliorate poverty and inequality, the WB simultaneously enacts contradictory policies. The WB-mandated neoliberal pension reforms in Brazil were used to redirect funding to the BFP and consolidate the social service programs and government ministries. Murphy (2008) 
contends that WB actions deepen poverty, making realization of the social objectives unachievable. Drawing on Tajikistan in 2002, Murphy (2008) notes that after the WB established that "'unemployment and underemployment rates in Tajikistan are high, and this is a basic source of poverty" (p. 63), it also insisted that "downsizing the public sector should form part of the reform package" (p. 63).

\subsection{A Human Capital Development Strategy}

Throughout the JDH and BFP documents, a singular theme emerges, that of human capital. Social inequality is approached and socially-constructed, overarchingly, as an issue of human capital development and distribution - and therefore as an economic and labour issue. For instance, in a statement outlining the objectives of WB involvement in the BFP, the documents state that the provision of US\$500 million is for reducing gaps and duplications in government coverage by CCTs, "as part of a broader and balanced strategy for economic and human capital development" (WB, 2004a, p. 6). Social inequality is conceptualized primarily as an issue of uneven capital distribution throughout a population; it is an issue of economic concern, and an issue that can be solved through economic policy and incentive.

\subsubsection{Citizens as Articles of Investment}

Citizens and populations are conceptualized as commodities of policy manipulation; they are human capital. As explained, "Investments in both the BFP, and in the supply and quality of health and education services, are thus crucial elements of a balanced human capital development strategy" (WB, 2004a, p. 3). This human capital conceptualization of poor populations is mirrored in the JDH project documents, where poor persons are understood as proper investments for cultural, social, health, and economic capital: "Broad objectives of the BFP are to reduce poverty and inequality and promote human capital investments among poor families (including indigenous and Quilombola populations) through the provision of direct monetary transfers to poor families and incentives for investing in human capital" (WB, 2004a, p. 4). This human capital investment is articulated by the WB as key to the overall agenda of developing the economies and societies of Argentina and Brazil. The broader idea of development is described as: "[support bridge-fostering between BFP and other beneficiaries and services] so as to help promote their "emancipation" (development) so as to help them escape from poverty" (WB, 2004a, p. 3). In this quote, the WB substitutes the Brazilian government's term, "emancipation," with the word, "development." This rewording implies that the WB conflates its economic development paradigm with a social justice enterprise.

This exchange of wording illustrates a unique feature of the WB paradigm on inequality. The use of the word "development" connotes that social inequality is a natural part of the progression of society, an economic entity uncomplicated by rights or inequities, whereby economic "development" ultimately cures inequalities; however, the use of the word "emancipation" implies an acknowledgement of a socialist-style understanding of an oppression of the poor. Thus, the WB conflates social justice and economic development through its wording in order to build a social construction of social inequality as an issue of human capital development, not only an issue of emancipation from injustices. This construction as human capital development allows for the insertion of social inequality projects into the broader global capitalist development goals. This motivation is explicit in the following quote from the JDH project: "First, reforms and policies that will ... improve their [Argentineans] human capital, increase productivity and their ability to compete in an increasingly globalized economy" (WB, 2002a, p. 4). In the context of the JDH project of Argentina, the WB promotes a human capital growth strategy to address the issue of social inequality.

Thus, the JDH documents position social inequality primarily as an economic issue and citizens as rational economic actors. The documents' language presents investing in education and skilled-work training (investing in "human capital") as the key to overcoming poverty in Argentina. The JDH is a CCT program paid for by the WB and the Argentinean Ministry of Labour JDH program. It is administered through municipal governments with payments going to the heads of individual households, conditional on their involvement in community workfare projects or educational training.

The JDH project facilitates the mitigation of social inequality and the development of unemployed persons' human capital through work-fare projects and education: "[It] provides 150 Argentine pesos/month to an unemployed head of household in exchange for participation in 4 hours of work in community services, small construction or maintenance activities, or training, including finishing basic education, or as a temporary employee of a private company" (WB, 2002a, p. 2). That is, the JDH is concerned with re-integrating unemployed persons into the economic system via the support and maintenance of their human capital. Notably, the JDH is focused on the unemployed population, not necessarily mitigating the poverty of the employed but destitute. Furthermore, the household must contain at least one of the following: children under the age of 18, handicapped of any age, or a pregnant woman. The JDH focuses its support on economically-viable units within society, missing key groups of the vulnerable population, such as orphaned children, the solitary elderly, and the abandoned handicapped. 


\subsubsection{Social Inequality as an Issue of Inefficient Human Capital Distribution}

Social inequality is an issue of deficiencies in the distribution of human capital and social capital. To grow the human capital of poor persons in Brazil and thus mitigate levels of social inequality, the BFP was constructed with a health and education component. Involving the use of health-care conditionalities for mothers and young children who are to receive the Bolsa Familia CCTs - for example, making vaccinations and maternal health care mandatory - the WB frames population health as a means to strong labour forces that can contribute to the economy. The BFP CCTs are designed to directly improve poor families' health outcomes, focusing on the children and persons of working age; this can be seen in how the mother is the choice redistributive recipient of the CCT. Furthermore, the BFP CCT is organized to improve health outcomes by providing consistent funds for food sustenance for families. The CCTs are inflation-controlled for fluctuations in food prices.

The WB defends its support of the BFP's CCTs by stating that the BFP is "non-assistentialist," implying that the BFP dissuades state-welfare dependency. Instead, it claims that the CCTs foster desirable education and health care behaviours that promote the growth of population human capital, and not "socially inappropriate ends" (WB, 2004a, p. 7). The mother is chosen as each household's primary CCT beneficiary, on the premise that she is most concerned with intra-household well-being. The WB wants to limit "welfare-dependency" by linking beneficiaries to complementary health and education services so they can "grow out of poverty" (WB, 2004a, p. 7). Thus, the BFP can be understood chiefly as a human capital growth strategy, whereby the WB appropriates a discourse of social justice to serve global economic development goals.

Importantly, the WB does not frame social inequality as a public health issue or as an issue of social justice and human rights. This finding for social inequality corroborates McCormick's (2012) study of the WB's approach to education development programs in Cambodia and Laos, and Goldman's (2007) study of WB water infrastructure projects in sub-Saharan Africa.

\section{Discussion and Conclusion}

\subsection{Creating Contradictions: The World Bank Approach}

By involving itself in projects such as the Jefes de Hogar and Bolsa Familia, the WB discursively and economically engages in the "emancipation" of the Latin American poor from dire economic conditions. Yet simultaneously, it encourages free-market expansion and transnational corporations' domination in national markets - this includes the effect of promoting land foreclosure and the tragedy of the commons for residents who depend on the land to live. These neoliberal economic practices are consistent with historical activity by the WB since the 1980s in Latin America, which have been shown to increase social inequality and vulnerability of the poor in both countries (McNally, 2006). For example, the WB concurrently supports the free-trade and deregulation of transnational mining and natural resource companies' operation in Argentina and Brazil. Such economic activities increase GDP growth of national markets; however, the negative social, political, environmental, and health consequences of deregulated multinational mining companies in Argentina and Brazil are extreme (Deneault \& Sacher, 2012). Thus, what the WB professes to fix with its social policy promotion, it has also helped to create by supporting the unmitigated expansion of MNCs' power.

\section{2 "A Soft-Faced Approach"}

The WB's use of social policy as appeasement was found to be the tact taken by MNCs active in Argentina and Brazil between 2000 and 2010, with corporate social responsibility campaigns making the front-stage in MNCs' Latin American public persona. Private US corporations are taking a "soft-faced" approach to Latin American development, investing large amounts in corporate social responsibility projects in order to create corporate citizenship in the countries believed to hold high investment returns (Torres-Baumgarten \& Yucetepe, 2009). The WB's involvement in social policy in Argentina and Brazil is part of a broader trend of the transnational-capitalist class: using social responsibility to the poor as appeasement for further continuance of global free-market expansion.

Authors such as Dello Buono (2011), De Ferranti (2004), Teubal (2004), and Cornia (2010) have argued that neoliberalism (in ideology and in practice) has collapsed in Latin America. Citing projects such as the JDH and the BFP, they claim a "new left" has arisen in the Latin American political sphere, eclipsing the neoliberal-growth ideologies of the past 30 years. However, close analyses of the JDH and BFP suggest this "new left" uses broad-based social policies to mask the exigencies of highly-unstable neoliberal globalized markets and to enable further long-term free-market economic growth.

\subsection{Social Policies of Appeasement}

The WB documents reveal an acceptance of social policy so long as it facilitates and maintains a highly-exploitive (growth-oriented) globalized capitalist system of development. As Santos (2010) explains, CCT programs such as the JDH or BFP are preferable social policy responses for free-market advocates; they require minimum participation of the 
state in the economy and are efficient in focusing on the poor while avoiding problems of bad governance. That is, the WB's promotion of CCT-usage by Argentina and Brazil facilitated social policy that minimized interference with neoliberal economic systems. Instead of neoliberalism's extinction in Latin America (as Cornia (2010) and Dello Buono (2011) suggest), the JDH and BFP show how neoliberal rationality has extended its grip into the realm of social policy.

Both the Jefes de Hogar and Bolsa Familia were instituted only after significant demonstrations of discontent by the poor and the masses, threats to political and economic stability if no political action was taken. As Hall (2008) articulates, appeasement for the ills of disastrous structural adjustment polices was a motive both for Brazilian President Lula's concentrated spending on the BFP (at the expense of other social programs), and for WB support spending on such social protection measures as the BFP in Brazil and the JDH program in Argentina. Teubal (2004) agrees, stating that the Argentinean economic collapse of 2001-2002 resulted from a "crisis of neoliberalism," caused in part by the WB-promoted structural adjustments of the 1980s and 1990s. Both projects were instituted after significant economic instability and recurring fiscal crises: Argentina, 2001-2002; Brazil, 1999 and 2001. Argentina invoked the Jefes de Hogar project as the direct and primary response to drastically rising poverty rates and increasing social inequality resultant from an economic depression. The WB's involvement in the JDH can be considered a form of social protection to allow for the stabilization of capitalism in Argentina. Kostzer (2008) and the WB (2007) agree that the JDH functioned as an effective policy to mitigate the instability of Argentina's economy and to stimulate economic recovery.

In conclusion, the WB appears to be co-opting the use of the UN's MDGs for global neoliberal development goals. Although it has helped achieve several of the MDGs, the WB remains fundamentally an organization interested in promoting and fostering a globalized economic system based on the ideology of free-trade neoliberalism. This fundamental positionality is evident even in its foray into Keynesianism with its support of the social policy projects in Argentina and Brazil. The WB's involvement in social inequality projects can be aptly described as an effort to maintain socially-stable societies for world economic exploitation by the dominant transnational class, rather than the more altruistic motivation of providing justice and quality of life for all. Overall, the Jefes de Hogar project of Argentina and the Bolsa Familia Program of Brazil illustrate how neoliberal rationality continually extends and consolidates its influence in a globalized world. The extent to which neoliberalism continues to extend itself in Latin America will depend on the success of the people resisting it (De la Barra, 2010).

\section{References}

Abouharb, M., \& Cingranelli, D. (2007). Human rights and structural adjustment. Cambridge, UK: Cambridge University Press.

Belizán, J. M., Cafferata, M. L., Belizán, M., \& Althabe, F. (2007). Health inequality in Latin America. The Lancet, 370(9599), 1599-1600. http://dx.doi.org/10.1016/S0140-6736(07)61673-0

Berger, P.L., \& Luckmann, T. (1966). The social construction of reality: A treatise in the sociology of knowledge. New York: Anchor Books.

Biggs, B., King, L., Basu, S., \& Stuckler, D. (2010). Is wealthier always healthier? The impact of national income level, inequality, and poverty on public health in Latin America. Social Science \& Medicine, 71(2), $266-273$. http://dx.doi.org/10.1016/j.socscimed.2010.04.002

Bourguignon, F. \& Pereira da Silva, L.A. (Eds.) (2003). The impact of economic policies on poverty and income distribution: Evaluation techniques and tools. Washington, DC: World Bank \& Oxford University Press.

Brazil. (2004). Brazil - Bolsa Familia project: Indigenous peoples plan - report no. IPP85. Brasilia: Government of Brazil. Retrieved April 20, 2013, from http://documents.worldbank.org/curated/en/2004/05/3433677/brazil-bolsa-familia-project-indigenous-peoples-plan

Brooks, S. M. (2007). Globalization and pension reform in Latin America. Latin American Politics and Society, 49(4), 31-62. http://dx.doi.org/10.1111/j.1548-2456.2007.tb00391.x

Castro, J. E. (2007). Poverty and citizenship: Sociological perspectives on water services and public-private participation. Geoforum, 38(5), 756-771. http://dx.doi.org/10.1016/j.geoforum.2005.12.006

Cornia, G. A. (2010). Income distribution under Latin America's new left regimes. Journal of Human Development and Capabilities, 11(1), 85-114. http://dx.doi.org/10.1080/19452820903481483

Cramer, B., \& Kaufman, R. (2010). Views of economic inequality in Latin America. Comparative Political Studies, 44(9), 1206-1237. http://dx.doi.org/10.1177/0010414010392171

De Ferranti, D. M. (2004). Inequality in Latin America: Breaking with history? Washington, DC: World Bank. http://dx.doi.org/10.1596/0-8213-5665-8 
De la Barra, X. (2010). Sacrificing neoliberalism to save capitalism: Latin America resists and offers answers to crises. Critical Sociology, 36, 635-666.

Dello Buono, R. A. (2011). Latin America and the collapsing ideological supports of neoliberalism. Critical Sociology, 37(1), 9-25. http://dx.doi.org/10.1177/0896920510383341

Deneault, A., \& Sacher, B. (2012). Imperial Canada Inc.: Legal haven of choice for the world's mining industries. Vancouver: Talonbooks.

Etienne, C.F. (2013). Equity in health systems. Rev Panam Salud Publica, 33(2), 79-80.

Goldman, M. (2007). How "Water for all!" policy became hegemonic: The power of the World Bank and its transnational policy networks. Geoforum, 38(5), 786-800. http://dx.doi.org/10.1016/j.geoforum.2005.10.008

Gottschalk, R., \& Justino, P. (2005). Overcoming inequality in Latin America: Issues and challenges for the twenty-first century. London: Routledge.

Hall, A. (2008). Brazil's Bolsa Familia: A double-edged sword? Development and Change, 39(5), 799-822. ISSN $1467-7660$

Hook, D. (2001). Discourse, knowledge, materiality, history: Foucault and discourse analysis. Theory \& Psychology, 11(4), 521-547. http://dx.doi.org/10.1177/0959354301114006

Huber, E. (2009). Politics and inequality in Latin America. PS: Political Science and Politics, 42(4), 651-655. http://dx.doi.org/10.1017/S1049096509990084

Kostzer, D. (2008). Argentina: A case study on the Plan Jefes y Jefas de Hogar Desocupados, or the employment road to economic recovery. Annandale-on-Hudson, New York: Levy Economics Institute.

Lee, K., Sridhar, D., \& Patel, M. (2009). Bridging the Divide: Global governance of trade and health. The Lancet, 373(9661), 416-422.

Lustig, N., Lopez-Calva, L.F., \& Ortiz-Juarez, E. (2012). Declining inequality in Latin America in the 2000s: The case of Argentina, Brazil, and Mexico. The World Bank Policy Research Working Paper 6248. http://www-wds.worldbank.org/servlet/WDSContentServer/WDSP/IB/2012/10/23/000158349_20121023093211/R endered/PDF/wps6248.pdf

McCormick, A. (2012). Whose education policies in aid-receiving countries? A critical discourse analysis of quality and normative transfer through Cambodia and Laos. Comparative Education Review, 56(1), 18-47.

McNally, D. (2006). Another world is possible: Globalization \& anti-capitalism. Winnipeg: Arbeiter Ring Pub.

Munarriz, G. J. (2008). Rhetoric and reality: The World Bank development policies, mining corporations, and indigenous communities in Latin America. International Community Law Review, 10(4), 431-431. http://dx.doi.org/10.1163/187197308X356930

Murphy, J. (2008). The World Bank and global managerialism. New York: Routledge.

Nuruzzaman, M. (2007). The World Bank, health policy reforms and the poor. Journal of Contemporary Asia, 37(1), 59-72. http://dx.doi.org/10.1080/00472330601104599

Ruger, J. P. (2005). The changing role of the World Bank in global health. American Journal of Public Health, 95(1), 60-70. http://dx.doi.org/10.2105/AJPH.2004.042002

Santos, L.M., (2010). Bolsa Familia Programme: Economic and social impacts under the perspective of the capabilities approach. London: University of London Press.

Teubal, M. (2004). Rise and collapse of neoliberalism in Argentina: The role of economic groups. Journal of Developing Societies, 20(3-4), 173-188. http://dx.doi.org/10.1177/0169796X04050957

Torres-Baumgarten, G., \& Yucetepe, V. (2009). Multinational firms' leadership role in corporate social responsibility in Latin America. Journal of Business Ethics, 85(1), 217-224. http://dx.doi.org/10.1007/s10551-008-9940-8

Wall, D. (2005). Babylon and beyond: The economics of anti-capitalist, anti-globalist, and radical green movements. Ann Arbor, MI: Pluto Press.

Wodak, R., \& Meyer, M. (Eds.). (2009). Methods of critical discourse analysis. Los Angeles: SAGE Publications.

World Bank. (2002a). Argentina - Jefes de Hogar (heads of household) program project: Report no. 23710 - Project appraisal document. Washington, DC: World Bank. Retrieved April 20, 2013, from http://documents.worldbank.org/curated/en/2002/10/2047953/argentina-jefes-de-hogar-heads-household-programproject 
World Bank. (2002b). World Bank annual report 2002: Volume 1, Main report. Washington, DC: World Bank. Retrieved April 20, 2013, from http://documents.worldbank.org/curated/en/2002/01/2017572/world-bank-annual-report-2002-vol-1-2-main-report

World Bank. (2004a). Brazil - First Bolsa Familia APL project: Report no. AB 559 - Project information document. Washington, DC: World Bank. Retrieved April 20, 2013, from http://documents.worldbank.org/curated/en/2004/04/3219327/brazil-first-bolsa-familia-apl-project

World Bank. (2007). Argentina - Jefes de Hogar (heads of household) program project: Report no. ICR355 Implementation completion and results report. Washington, DC: World Bank. Retrieved April 20, 2013, from http://documents.worldbank.org/curated/en/2007/09/9047529/argentina-jefes-de-hogar-heads-household-programproject

World Bank. (2010a). Argentina - Heads of household transition project: Report no. ICR1395 - Implementation completion and results report. Washington, DC: World Bank. Retrieved April 20, 2013, from http://documents.worldbank.org/curated/en/2010/04/12881879/argentina-heads-household-transition-project

World Bank. (2010b). Brazil - Bolsa Familia project: Report no. ICR00001486 - Implementation completion and results report (IBRD-72340) on a loan in the amount of US\$572.2 million to the Federative Republic of Brazil for a Bolsa Familia project in support of the first phase of the Bolsa Familia program. Washington, DC: World Bank. Retrieved April 20, 2013, from

http://documents.worldbank.org/curated/en/2010/06/12568141/brazil-bolsa-familia-project

World Bank. (2013a). Mission. In About us. Retrieved April 20, 2013, from http://web.worldbank.org/WBSITE/EXTERNAL/EXTABOUTUS/0,,pagePK:50004410 piPK:36602 theSitePK:2 9708,00.html

World Bank. (2013b). World Bank History. In Archives. Retrieved March 25, 2013, from http://web.worldbank.org/WBSITE/EXTERNAL/EXTABOUTUS/EXTARCHIVES/0,,contentMDK:20053333 m enuPK:63762 pagePK:36726 piPK:36092 theSitePK:29506,00.html

\section{(cc) $\mathrm{EY}$}

This work is licensed under a Creative Commons Attribution 3.0 License. 